\title{
Causes and Risk Factors of Hospitalization among Under-five Children in Kassala, Eastern Sudan
}

\author{
Ahmed A. Hassan ${ }^{1}$, Zainab Taha ${ }^{2 \star}$, Mohammed A. Abdulla ${ }^{3}$, AbdelAziem A. Ali $^{4}$, Ishag Adam ${ }^{5}$ \\ ${ }^{1}$ Department of Research, Taami for Agricultural and Animal Production, Khartoum, Sudan; ${ }^{2}$ Department of Health Sciences, \\ College of Natural and Health Sciences, Zayed University, Abu Dhabi, United Arab Emirates; ${ }^{3}$ Department of Pediatrics, Faculty \\ of Medicine, Gadarif University, Sudan; ${ }^{4}$ Department of Obstetrics and Gynecology, Faculty of Medicine, Kassala University, \\ Sudan; ${ }^{5}$ Department of Obstetrics and Gynecology, Unaizah College of Medicine and Medical Sciences, Qassim University, \\ Unaizah, Kingdom of Saudi Arabia
}

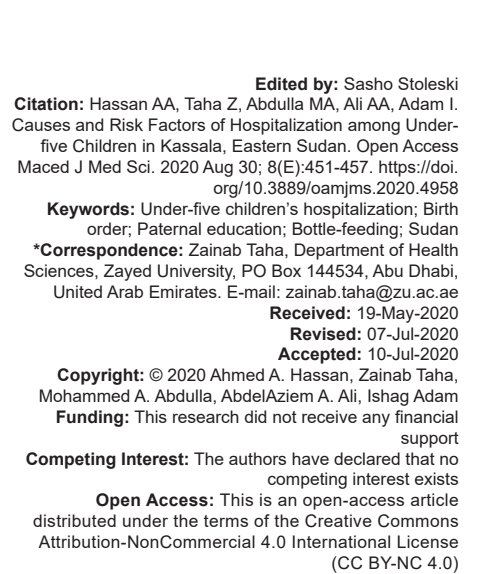

\begin{abstract}
BACKGROUND: According to the World Health Organization estimation, African Region deaths of all under-five deaths in 2015 were over 5 times higher in comparison to the European Region.

AIM: The study aimed to estimate the prevalence, investigate the possible causes and risk factors associated with under-five children's hospitalization in Kassala, Eastern Sudan.

METHODS: A community-based cross-sectional study was conducted from December 2015 to March 2016 . The data were collected by interviewing mothers.

RESULTS: A total of 297 mother-child pairs participated in the study. The mean (SD) of maternal age and children's age was 27.6 (5.9) years and 16 (11.3) months, respectively. One hundred and three children were hospitalized over the past 6 months. The most common mentioned causes for the last hospitalization were gastroenteritis $28.1 \%(29 / 103)$, respiratory tract infections $19.4 \%(20 / 103)$, malaria $9.7 \%(10 / 103)$, and trauma 3.8\% $(3 / 103)$ In multivariable analysis, a high birth order (adjusted odds ratio [AOR] 1.25, 95\% Confidence Interval [Cl] $(1.06$ 1.47), low paternal education (AOR 2.89, 95\% 1.32, 6.30), and bottle feeding (AOR $2.26,95 \% \mathrm{Cl} 1.30,3.80$ ) were
\end{abstract} associated with under-five children's hospitalization.

CONCLUSIONS: More than one-third of the children were hospitalized in Eastern Sudan. Urgent action is required to address children's health issues (i.e., the above-mentioned causes and associated factors).

\section{Introduction}

According to the World Health Organization (WHO), in 2015, 4.5 million (75\%) of all under-five deaths occurred within the $1^{\text {st }}$ year of life and the highest risk was in the WHO African Region (55/1000 live births). This is over 5 times higher in comparison to the European Region (10/1000 live births) [1].

Based on the results of the previous studies on under-five children's hospitalization, the predictors of admission were non-exclusive breastfeeding; delay of initiation of breastfeeding; bottle-feeding; unemployed mothers; having two or more children; and complementary feeds given by a person other than the mother; prolonged rupture of membrane; place of delivery; intrapartum fever; and APGAR score $<7$ at $5^{\text {th }}$ min [2], [3], [4], [5], [6], [7], [8], [9]. Likewise, exclusive breastfeeding and avoidance of bottle feeding have been documented as key predictors of child survival [9], [10], [11], [12]. Besides, child hospitalization has a heavy burden on the economy [4], [13]. The main causes of admission reported by the previous studies including Sudan were respiratory tract infections and gastroenteritis [2], [4], [5], [6], [7], [8].

Unfortunately, in Sudan, infants and young children are the most vulnerable ones among the population [2]. Child hospitalization rates, as well as causes and risk factors, have been studied in many countries [4], [5], [6], [14], [15], [16], [17]. However, little data exist in Sudan, especially in the most vulnerable and remote areas.

Kassala, located in Eastern Sudan, was selected to study children's hospitalization for several reasons. First, most of the available data in Sudan regarding child hospitalization were hospital-based studies [9], [18], [19]. Furthermore, the target area of Kassala State is categorized to be among the most vulnerable states where high rates of acute and chronic malnutrition have been reported, especially among children [20]. Most of the previous studies on children's hospitalization were carried out in the capital state of Khartoum and the nearby areas [18], [19] which is a relatively stable region. In contrast, Kassala is 
characterized by refugees' settlement mainly from the neighboring country Eritrea from early eighth of the last century [21], [22]. It has had an influx of refugees from that time until now (i.e., according to the last report, influxes of refugees from Eritrea continue on average at a rate of approximately 2000 per month). This has increased Kassala's population and has put stress on the already limited resources [22], [23], [24]. The previous reports for both food [23] and security [25], as well as the recent report for food [26], have shown that Kassala is more vulnerable to humanitarian crises. In the context of food insecurity and unstable security, child morbidly and mortality, especially the under-fives, is found to be high and damaging [27], [28], [29], [30], [31], [32]. Both food insecurity and unstable security are linked to each other [33] as unstable security limits the provision of food production and distribution as well as health-care provision such as child vaccination [29], [34]. Besides, the availability of data before the crisis is of paramount importance to build on when a crisis occurs.

Conducting such a study at a community-level in an area characterized by both food insecurity and unstable security is, therefore, of great importance toward identifying the magnitude of the problem and will ultimately provide the basis for a future communitybased intervention. Sudan is one of those developing countries where the rationale use of resources should always be strategic. Furthermore, such kind of research is needed to understand the gap and to prioritize the interventions for child life saving which this study aimed to achieve.

The study aimed to estimate the prevalence of under-five children's admission to health-care facilities and to investigate the possible causes and risk factors over the past 6 months in Kassala, Eastern Sudan by collecting community-level data.

\section{Methods}

A two-stage random (using a computergenerated number) cluster study was conducted in Kassala, Eastern Sudan from December 2015 to March 2016. Kassala is the capital of Kassala State. Kassala is $550 \mathrm{~km}$ from Khartoum on Ethiopian-Eritrean borders. Kassala has an estimated population of 453,159 inhabitants [35]. In stage one, simple random sampling of the localities was performed to randomly identify the household. In stage two, random sampling of the households was done to identify subjects (under-five children).

The houses were mapped to select a representative sample. The main tool used to collect data, in this study, was a structured pretested questionnaire. The questionnaire was tested among 15 participants (i.e., not considered in the final data) and the necessary corrections were done accordingly. Five female medical officers were trained by the investigators to collect the data. The following inclusion criteria were set before conducting the study: Willingness to participate in the study, having under-five children (in case the mother had two children under-5 years and less, and the interview took place based on the youngest child), and availability at the time of data collection. The study excluded any mother, who did not fulfill the above-mentioned inclusion criteria.

A child was considered to be hospitalized when a child was admitted to a health-care facility complaining from any sickness and spent at least $24 \mathrm{~h}$ or more [36], [37]. A child admitted for $<24 \mathrm{~h}$ was included in the study but considered as not having been admitted. For example, a child who came for routine immunization was not considered as child hospitalization and was included in the study as non-hospitalized.

The target participant was approached and before collecting any data, the following information was delivered by the interviewer to the participant, that is, the study purpose was explained, the right to refuse atany time, and the confidentiality of the obtained information. After participant acceptance and success in fulfilling the study inclusion criteria, a questionnaire was applied to collect relevant information from mothers through a face-to-face interview. The questionnaire was developed based on the previous studies [9], [10], [11], [12], [13], [14], [15], [16], [17], [18], [19]. It included demographics (e.g., education, age, and occupation), mode of delivery (vaginal delivery, and cesarean delivery), infant's information (e.g., age, gender, and history of hospitalization over the past 6 months), and the main cause for hospitalization. For children who were hospitalized more than once, the cause of hospitalization was based on the last hospitalization.

A sample size of 309 participants was calculated using the assumption of the prevalence of $(27.8 \%)$ which was reported in the previous community survey among children below the age of 5 years in Sudan [38]. This sample was selected to give $80 \%$ power with a precision of $5 \%$.

\section{Statistical analysis}

The questionnaire was coded, for example, the main outcome variable (child hospitalization) was coded as (0) and (1) for not hospitalized and hospitalized, respectively.

Data were entered into the computer using Statistical Package for the Social Sciences version 20.0 for Windows, International Business Machines Corporation (IBM Corp, New York, United States), and doublechecked before analyses. The results were illustrated in tables and text by calculating the means and SD for continuous variables, and frequencies and percentages for categorical variables to describe the participants' responses. t-test and Chi-square were applied for the 
continuous and the categorical variable, respectively. Univariate analysis was applied with child hospitalization (hospitalized/not hospitalized) as the dependent variable and the other variables (age, parity, education, residence, mode of delivery, the new-born gender, etc.) as the independent variable. Moreover, variables with $p<0.2$ were entered in multivariable analysis to control confounding variables. This cutoff $p<0.2$ was chosen because being significant (i.e., the variable) in univariate analysis but not significant in logistic regression and vice versa is not uncommon, as it has been explained in the literature [39], [40]. Odds ratio (OR), adjusted OR (AOR), and 95\% confidence interval $(\mathrm{Cl})$ were calculated. Variable with $p<0.05$ was considered as significant.

\section{Results}

From the total (309) enrolled mother-child pairs, 297 (96.1\%) had complete data. The mean (SD) of maternal age and children's age was 27.6 (5.9) years and 16 (11.3) months, respectively. Of these 297 participants, $122(41.1 \%)$ were a rural, 269 (88.6\%) were housewives, and $197(66.3 \%)$ had education less than the secondary level. Twenty-eight $(9.4 \%)$ of the mothers had medical disorders (diabetes, hypertension, and others). Less than half $137(46.1 \%)$ of the children were females. More than half $161(54.2 \%)$ of the children were institutional deliveries with a cesarean rate of $18.2 \%$. One hundred and fifteen $(38.7 \%)$ children were bottle-fed in the first 6 months.

Over the past 6 months, more than one-third of the children $34.7 \%$ (103/297) was hospitalized and spent $24 \mathrm{~h}$ or more at the hospital at least 1 time over the past 6 months.

The most commonly mentioned causes of hospitalization over the past 6 months based on the last hospitalization were gastroenteritis $28.1 \%$ (29/103), respiratory tract infections $19.4 \%(20 / 103)$, malaria $9.7 \%$ (10/103), and trauma 3.8\% (3/103).

Residence and maternal education were found to be significant in univariate analysis only (Table 1).

In multivariable analysis (Table 2), a high birth order (AOR 1.25, 95\% Cl 1.06, 1.47), low paternal education (AOR 2.89, 95\% 1.32, 6.30), and bottle feeding (AOR 2.26, 95\% Cl 1.30, 3.80) were associated with hospitalization of the under-five children.

\section{Discussion}

The main finding of the current study was that more than one-third $(34.7 \%)$ of the studied children were hospitalized over the past 6 months. This prevalence was higher in comparison to the prevalence which was reported in Nigeria (9.7\%) [14], in the United Arab Emirates (UAE) (10\%) [15] and Ethiopia (21.5\%) [16]. The difference could be due to the study methodologies as this is a community based one.

The commonly reported causes of admissions over the past 6 months were respiratory tract infections, gastroenteritis, and malaria. This is consistent with the previous reports in Sudan where the most common clinical presentations for under-five children were gastroenteritis, malaria, urinary tract infections, giardiasis, and tuberculosis [18], [41]. Likewise, the previous studies conducted in food insecurity areas showed that respiratory infection and gastroenteritis were the common causes of under-five children's hospitalization [17], [27], [32], [42].

Table 1: Socio-demographic characteristic of the under-five children's hospitalization in Kassala, Eastern Sudan $(n=297)$

\begin{tabular}{|c|c|c|c|c|}
\hline \multirow[t]{2}{*}{ Variable } & \multicolumn{4}{|c|}{$\begin{array}{l}\text { Total }(n=297) \text { Child hospitalization (hospitalized } \\
n=103),(\text { non-hospitalized } n=194)\end{array}$} \\
\hline & Mean (SD) & Mean (SD) & Mean (SD) & p-value \\
\hline Maternal age, years & $27.6(5.9)$ & $27.1(6.3)$ & $27.8(5.7)$ & 0.366 \\
\hline Child age, months & $16.0(11.4)$ & $17.6(11.9)$ & $15.2(11.1)$ & 0.086 \\
\hline \multirow[t]{2}{*}{ Birth order } & $2.5(1.6)$ & $2.9(1.9)$ & $2.3(1.4)$ & 0.006 \\
\hline & $\mathrm{n}(\%)$ & $\mathrm{n}(\%)$ & $\mathrm{n}(\%)$ & \\
\hline \multicolumn{5}{|l|}{ Child gender } \\
\hline Male & $160(53.9)$ & $55(53.4)$ & $105(54.1)$ & 0.905 \\
\hline Female & $137(46.1)$ & $48(46.6)$ & $89(45.9)$ & \\
\hline \multicolumn{5}{|l|}{ Residence } \\
\hline Rural & $122(41.1)$ & $51(49.5)$ & $71(36.6)$ & 0.039 \\
\hline Urban & $175(58.9)$ & $52(50.5)$ & $123(63.4)$ & \\
\hline \multicolumn{5}{|l|}{ Mode of delivery } \\
\hline Cesarean & $54(18.2)$ & $16(15.5)$ & $38(19.6)$ & 0.389 \\
\hline Vaginal & $243(81.8)$ & $87(84.5)$ & $156(80.4)$ & \\
\hline \multicolumn{5}{|l|}{ Place of delivery } \\
\hline Institutional & $161(54.2)$ & $52(50.5)$ & $109(56.2)$ & 0.348 \\
\hline Home & $136(45.8)$ & $51(49.5)$ & $85(43.8)$ & \\
\hline \multicolumn{5}{|c|}{ Bottle-feeding in the first 6 months } \\
\hline Yes & $115(38.7)$ & $52(50.5)$ & $63(32.5)$ & 0.002 \\
\hline No & $182(61.3)$ & $51(48.1)$ & $131(67.5)$ & \\
\hline \multicolumn{5}{|l|}{ Maternal education } \\
\hline$<$ Secondary level & $197(66.3)$ & $82(79.6)$ & $115(59.3)$ & $<0.001$ \\
\hline$\geq$ Secondary level & $100(33.7)$ & $21(20.4)$ & $79(40.7)$ & \\
\hline \multicolumn{5}{|l|}{ Paternal education } \\
\hline$<$ Secondary level & $167(56.2)$ & $75(72.8)$ & $92(47.4)$ & $<0.001$ \\
\hline$\geq$ Secondary level & $130(43.8)$ & $28(27.2)$ & $102(52.6)$ & \\
\hline \multicolumn{5}{|c|}{ Maternal medical history } \\
\hline Yes & $28(9.4)$ & $12(11.7)$ & $16(8.2)$ & 0.339 \\
\hline No & $269(90.6)$ & $91(88.3)$ & $178(91.8)$ & \\
\hline \multicolumn{5}{|l|}{ Maternal occupation } \\
\hline Housewife & $262(88.2)$ & $96(93.2)$ & $166(85.6)$ & 0.052 \\
\hline Employed & $35(11.8)$ & $7(6.8)$ & $28(14.4)$ & \\
\hline
\end{tabular}

Table 2: Multivariable logistic regression analyses of factors associated with the under-five children's hospitalization in Kassala, Eastern Sudan

\begin{tabular}{|c|c|c|c|}
\hline Variables & Crude OR $(95 \% \mathrm{Cl})$ & AOR $(95 \% \mathrm{Cl})$ & $p$-value \\
\hline Child age & $1.02(0.99,1.04)$ & $1.02(0.996,1.043)$ & 0.101 \\
\hline High child order & $1.23(1.06,1.43)$ & $1.25(1.06,1.47)$ & 0.011 \\
\hline Residence & & & \\
\hline $\begin{array}{l}\text { Rural } \\
\text { Urban (reference) }\end{array}$ & $1.67(1.03,2.71)$ & $1.10(0.62,1.95)$ & 0.738 \\
\hline Bottle feeding & & & \\
\hline $\begin{array}{l}\text { Yes } \\
\text { No (reference) }\end{array}$ & $2.12(1.30,3.46)$ & $2.26(1.3,3.8)$ & 0.002 \\
\hline Maternal education & & & \\
\hline $\begin{array}{l}<\text { Secondary level } \\
\geq \text { Secondary level (reference) }\end{array}$ & $2.68(1.54,4.69)$ & $1.21(0.50,2.89)$ & 0.677 \\
\hline $\begin{array}{l}\text { Paternal education } \\
<\text { Secondary level } \\
\geq \text { Secondary level (reference) }\end{array}$ & $2.97(1.77,4.98)$ & $2.89(1.32,6.30)$ & 0.009 \\
\hline $\begin{array}{l}\text { Maternal occupation } \\
\text { Housewife } \\
\text { Employed (reference) }\end{array}$ & $2.31(0.97,5.50)$ & $1.13(0.40,3.17)$ & 0.820 \\
\hline
\end{tabular}

The current study showed a high rate of bottle feeding $(38.7 \%)$ and children who were bottle-fed were 
at 2.26 higher risk of hospitalization. In Khartoum, among bottle-fed infants, 100 and ten bacterial species including Escherichia coli were isolated from contents [43]. Many studies documented that poor breastfeeding practices (e.g., using bottle feeding) were the main key risk factor for children's hospitalization mainly due to respiratory tract infection and gastroenteritis[2], [4], [5], [6], [7], [8], [9]. Breastfeeding, particularly when exclusive and prolonged, protects against severe morbidities such as diarrhea and respiratory infections [4]. Various studies documented that bottle-feeding is associated with child morbidity (e.g., diarrhea, respiratory infection, and allergies) and mortality [9], [10], [43], [44], [45], [46]. For example, in Sudan, bottle-fed children were at high risk of malnutrition and hospitalization due to infectious causes as $83.3 \%$ of hospitalized children used bottle feeding [9].

The result of the current study showed that high birth order was a risk factor for child survival. In line with the current results, high birth order was reported by many studies in different countries including Sudan as a key risk factor for poor children's health due to morbidity and mortality [9], [47], [48], [49], [50]. This could be explained by the fact that high parity and extensive periods of breastfeeding presumably result in deletion of the reserved maternal nutrition such as anemia [51], and this could lead to a low birth outcome with its catastrophic effects [52]. In addition, in Sudan, Ibrahim, and Nabag found that the majority of the under-five malnourished children had increased birth order (i.e., their birth order was second and above). They attributed the effects of higher birth order on child health to access to less food and reduced time received per child [9].

The study showed that paternal education level ( $\geq$ Secondary level) was higher in comparison to maternal education $43.8 \%$ and $33.7 \%$, respectively. Such variations between paternal and maternal education in Sudan have been reported previously [9]. This variation of education levels was also reflected in the employment rate as only $12 \%$ of the mothers were employed. This may raise the issue of gender inequality in both education and employment. In Africa, education gender-based inequality is not only confined to the years and level of education but also in the provided quality of the education itself, that is, poor quality for girls at schools [53].

Unlike maternal education, high level of paternal education was found to be a protective factor of child hospitalization. In line with the current results, other studies reported that maternal education does not influence the incidence of child morbidity and mortality [53], [54]. Interestingly, Sudan Household Health Survey 2000 revealed a positive correlation between maternal education and incidence of diarrheal diseases, that is, high maternal education level associated with a high rate of diarrheal diseases [41]. In contrast, the previous studies in different regions of
Sudan including the study area revealed that maternal education was associated with poor perinatal and maternal outcomes [55], [56]. This contradiction could be due to the complex relationship between parental education and child health and the necessity of the presence of others preconditioning factors (e.g., equity, and women empowerment), for education to be more effective in improving knowledge, the income, and child survival [50], [53], [57].

For example, regardless of maternal education, a child of an educated father was more likely to be vaccinated against measles [58]. The influence of paternal education on child hospitalization could be explained by the small family size (i.e., less birth order) as the evidence provided by the literature is that educated parents desire smaller families than those with less education [59], [60]. By having fewer children more time and care can be given to each child. Besides, parents with higher education level may have more chances of employment, as well as better socioeconomic status, better food security status, accessibility to health insurance, and more knowledgeable about child health [58], [59], [61], [62]. Thus, we can conclude that factors such as low paternal education and high child order are correlated. Therefore, in Sudan, the impacts of parent education on infants and young child health need to be explored through more research.

In this study, residence in rural or urban areas was not significantly associated with child hospitalization. In contrast to another study [63], residence showed associated with children's hospitalization only in the univariate analysis. A recent study in Bangladesh revealed that disparity between urban and rural residency regarding child health has decreased over time [50].

The study has given valuable information regarding child hospitalization. However, the study had some limitations such as recall bias and the causes of child hospitalization were only based on the mother's memory (i.e., not on hospital records). In addition, the comorbidities among the reported causes are not uncommon [42], [64], [65], [66] and even among children who were hospitalized for more than 1 time over the past 6 months different causes were observed between the first and second hypostatization; and the children's weights were not measured as they have been done in the previous studies [2], [4], [5], [6], [7], [8]. Furthermore, the study investigated only living children that were hospitalized and it failed to trace children who were hospitalized and died.

\section{Conclusions}

More than one-third of the children were hospitalized in Eastern Sudan. The most common 
mentioned causes of hospitalization were gastroenteritis, respiratory tract infections, malaria, and trauma. A high birth order, paternal education, and bottle feeding were associated with hospitalization of the under-five children. Urgent action is required to address children's health issues as the situation is fragile and unpredictable and the consequences will be more severe, if the situation worsens in the future.

\section{Authors' Contributions}

$\mathrm{AAH}, \mathrm{ZT}$, and IA designed the study and participated in the manuscript drafting. MAA, ZT, and AAA collected the data. AAH, AAA, and IA conducted the statistical analyses. All authors read and approved the final manuscript

\section{Acknowledgments}

We would like to thank all the study participants for their sincere cooperation and the provision of valuable information. We appreciate the work done by Ms. Sharon Kelly on improving the English language.

\section{References}

1. WHO. Infant Mortality; 2017. Available from: http://www.who int/gho/child_health/mortality/neonatal_infant_text/en. [Last accessed on 2019 Dec 05].

2. Mahgoub HM, Adam I. Morbidity and mortality of severe malnutrition among Sudanese children in new halfa hospital, Eastern Sudan sign in Oxford academic account. Trans R Soc Trop Med Hyg. 2012;106(1):66-8. https://doi.org/10.1016/j. trstmh.2011.09.003

3. Monge RB. Upper airway infections related to the use of the feeding bottle in feeding the young infant. Curr Nurs Costa Rica. 2017;32:90-103.

4. Hanieh S, Ha TT, Simpson JA, Thuy TT, Khuong NC, Thoang DD, et al. Exclusive breast feeding in early infancy reduces the risk of inpatient admission for diarrhea and suspected pneumonia in rural Vietnam: A prospective cohort study. BMC Public Health. 2015;15:1166. https://doi.org/10.1186/s12889-015-2431-9 PMid:26602368

5. Ajetunmobi OM, Whyte B, Chalmers J, Tappin DM, Uk M, Wolfson L, et al. Breastfeeding is associated with reduced childhood hospitalization: Evidence from a scottish birth cohort (1997-2009). J Pediatr. 2015;166(3):620-5.e4. https://doi. org/10.1016/j.jpeds.2014.11.013

PMid:25556021

6. Patel DV, Bansal SC, Nimbalkar AS, Phatak AG, Nimbalkar SM, Desai RG. Breastfeeding practices, demographic variables, and their association with morbidities in children. Adv Prev Med.
2015;2015:892825. https://doi.org/10.1155/2015/892825 PMid:26347823

7. KaurA, Singh K, Pannu MS, Singh P, Sehgal N, Kaur R. The effect of exclusive breastfeeding on hospital stay and morbidity due to various diseases in infants under 6 months of age: A prospective observational study. Int J Pediatr. 2016;2016:7647054. https:// doi.org/10.1155/2016/7647054

8. Gebremedhin D, Berhe H, Gebrekirstos K. Risk factors for neonatal sepsis in public hospitals of Mekelle City, North Ethiopia, 2015: Unmatched case control study. PLoS One. 2016;11(5):e0154798. https://doi.org/10.1371/journal.pone. 0154798 PMid:27163290

9. Sharaf A, Ibrahim E, Nabag FO. Impact of diarrhoea on the nutritional status among children under five years old. Sudan $\mathrm{J}$ Sci Technol. 2016;17(2):46-56.

10. Hussain Z, Khan N. Assessment of the nutritional status of bottle-fed infants and the prevalence of infections, allergy and diarrhea among bottle fed infants and its comparison with exclusively breast fed infants aged 0-6 months. J Pediatr Neonatal Care Assess. 2017;6(4):2-7. https://doi.org/10.15406/ jpnc.2017.06.00249

11. Biks GA, Berhane $Y$, Worku A, Gete YK. Exclusive breast feeding is the strongest predictor of infant survival in Northwest Ethiopia: A longitudinal study. J Health Popul Nutr. 2015;34:9. https://doi.org/10.1186/s41043-015-0007-z PMid:26825334

12. Awasthi A, Awasthi S. Promoting exclusive breastfeeding in India to reduce neonatal mortality. Clin Epidemiol Glob Health. 2016;4(4):151-2. https://doi.org/10.1016/j.cegh.2016.11.001

13. Thaver D, Zaidi AK. Burden of neonatal infections in developing countries: A review of evidence from community-based studies. Pediatr Infect Dis J. 2009;28(1):S3-9. https://doi.org/10.1097/ inf.0b013e3181958755

14. Muoneke VU, Ibekwe RC, Nebe-Agumadu HU, Ibe BC. Factors associated with mortality in under-five children with severe anemia in Ebonyi, Nigeria. Indian Pediatr. 2012;49(2):119-23. https://doi.org/10.1007/s13312-012-0026-4

PMid:21719933

15. Howidi M, Al Kaabi N, El Khoury AC, Brandtmüller A, Nagy L, Richer $E$. Burden of acute gastroenteritis among children younger than 5 years of age-a survey among parents in the United Arab Emirates. BMC Pediatr. 2012;12:74. https://doi. org/10.1186/1471-2431-12-74

PMid:22708988

16. Anteneh ZA, Andargie K, Tarekegn M. Prevalence and determinants of acute diarrhea among children younger than five years old in Jabithennan District, Northwest. BMC Public Health. 2017;17(1):99. https://doi.org/10.1186/s12889-017-4021-5 PMid:28103908

17. Pernica JM, Steenhoff AP, Welch H, Mokomane M, Quaye I, Arscott-Mills $\mathrm{T}$, et al. Correlation of clinical outcomes with multiplex molecular testing of stool from children admitted to hospital with gastroenteritis in Botswana. J Pediatric Infect Dis Soc. 2016;5(3):312-8. https://doi.org/10.1093/jpids/piv028 PMid:26407262

18. Kanan SO, Swar MO. Prevalence and outcome of severe malnutrition in children less than five-year-old in omdurman paediatric hospital, Sudan. Sudan J Paediatr. 2016;16(1):23-30. PMid:27651550

19. Elhassan EM, Hassan AA, Mirghani OA, Adam I. Morbidity and mortality pattern of neonates admitted into nursery unit in wad medani hospital, Sudan. Sudan J Med Sci. 2010;5(1):13-6. https://doi.org/10.4314/sjms.v5i1.56023

20. Sudan National S3M. Executive Summary: Simple Spatial Surveying Method (S3M) Survey in Sudan, Khartoum; 2013. 
Available from: http://www.coverage-monitoring.org/wp-content/ uploads/2014/12/sudan_s3m-_2013_final-endorsed-executivesummary_25nov2014.pdf. [Last accessed on 2019 Dec 10].

21. Ambroso G, Crisp J, Albert N. Review of UNHCR's Response to the Protracted Refugee Situation in Eastern Sudan. United Nations High Commissioner for Refugees Policy Development and Evaluation Service (PDES); 2011. Available from: https:// www.unhcr.org/4eb3e5ea9.pdf.

22. Abdalla IM. Shagarab land will Change into Desert by Refugees, El-Griba Locality, Kassala State, Sudan. Int J Curr Microbiol Appl Sci. 2015;4(9):784-8.

23. World Food Programme. A Comprehensive Food Security Assessment in Kassala State, Sudan UN World Food Programme; 2012. Available from: http://www.documents. wfp.org/stellent/groups/public/documents/ena/wfp258759. pdf?iframe. [Last accessed on 2019 Dec 10]. https://doi. org/10.1093/law:epil/9780199231690/e574

24. Kok W. Self-settled refugees and the socio-economic impact of their presence on kassala, Eastern Sudan. J Refug Stud. 2018;2(4):419-40. https://doi.org/10.1093/jrs/2.4.419

25. Ottaway M, El-Sadany M. Sudan: From Conflict to Conflict. Washington, DC: USA; 2012. Available from: http://www. carnegieendowment.org/files/sudan_conflict.pdf. accessed on 2019 Dec 11].

26. Sudan Integrated Food Security Phase Classification IPC. Sudan Acute Food Insecurity Situation, Khartoum, Sudan; 2017. Available from: http://www.documents.wfp.org/stellent/groups/ public/documents/ena/wfp258759.pdf?iframe. [Last accessed on 2019 Dec 10].

27. Gubert MB, Spaniol AM, Bortolini GA, Pérez-escamilla R. Household food insecurity, nutritional status and morbidity in Brazilian children. Public Health Nutr. 2016;19(12):2240-5. https://doi.org/10.1017/s1368980016000239 PMid:26893101

28. Campbell AA, de Pee S, Sun K, Kraemer K, Thorne-lyman A, Moench-Pfanner $\mathrm{R}$, et al. Relationship of household food insecurity to neonatal, infant, and under-five child mortality among families in rural Indonesia. Food Nutr Bull. 2009;30(2):112-9. https://doi.org/10.1177/156482650903000202 PMid:19689089

29. Nnadi C, Etsano A, Uba B, Ohuabunwo C, Melton M, Nganda G, et al. Approaches to vaccination among populations in areas of conflict. J Infect Dis. 2017;216(1):S368-72. https://doi. org/10.1093/infdis/jix175 PMid:28838202

30. Pereira AL, Handa S, Holmqvist G. Prevalence and Correlates of Food Insecurity Among Children Across the Globe, Florence, Italy; 2017. Available from: https://www.unicef-irc.org/publications/pdf/ iwp_2017_09.pdf. [Last accessed on 2019 Dec 10].

31. Betebo B, Ejajo T, Alemseged F, Massa D. Household food insecurity and its association with nutritional status of children 6-59 months of age in East Badawacho district, South Ethiopia. J Environ Public Health. 2017;2017:6373595. https://doi. org/10.1155/2017/6373595 PMid:28408936

32. Chowdhury MR, Khan MM, Islam, MR, Perera NK, Shumack MK, Kader M. Low maternal education and socio-economic status were associated with household food insecurity in children under five with diarrhoea in Bangladesh. Acta Paediatr. 2016;105(5):555-61. https://doi.org/10.1111/apa.13325 PMid:26719122

33. Brinkman H, Hendrix CS. Food Insecurity and Violent Conflict: Causes, Consequences, and Addressing the Challenges. Report No. 24. Rome, Italy; 2011. Available from: https://www. ucanr.edu/blogs/food2025/blogfiles/14415.pdf. [Last accessed on 2019 Dec 10].
34. Footer KH, Rubenstein LS. A Human Rights Approach to Health care in conflict. Int Rev Red Cross. 2013;95(889):167-87. https://doi.org/10.1017/s1816383113000349

35. Central Bureau of Statistics (CBS). Censuses, Sudan Goverment; 2018. Available from: http://www.cbs.gov.sd/en/ files. php?id=7\#\&panel1-3. [Last accessed on 2019 Dec 10].

36. The Organisation for Economic Co-Operation and Development. OECD Health Statistics 2017 Definitions, Sources and Methods Hospital Average Available from: Length of Stay by Diagnostic Categories; 2017. http://www.stats.oecd.org/fileview2. aspx?idfile=05c5f7a0-a813-4cc1-8a83-0d77343b5b9e. [Last accessed on 2019 Dec 13].

37. Beser OF, Cokugras FC, Erkan T, Kutlu T, Yagci RV, TUHAMAR Study Group. Evaluation of malnutrition development risk in hospitalized children. Nutrition. 2018;48:40-7. PMid:29469018

38. Siziya S, Muula AS, Rudatsikira E. Correlates of diarrhoea among children below the age of 5 years in Sudan. Afr Health Sci. 2013;13(2):376-83. https://doi.org/10.4314/ahs.v13i2.26 PMid:24235939

39. Wang $\mathrm{H}$, Peng J, Wang B, Lu X, Zheng JZ, Wang $\mathrm{K}$, et al. Inconsistency between univariate and multiple logistic regressions. Shanghai Arch Psychiatry. 2017;29(2):124-8. PMid:28765686

40. Lo SK, Li IT, Tsou TS, See L. Non-significant in univariate but significant in multivariate analysis: A discussion with examples. Changgeng Yi Xue Za Zhi. 1995;18(2):95-101. PMid:7641117

41. Li V, Davies K, Koizumi E, Paluch S, Riviere S, Summers M. Reducing child mortality in Sudan by preventing diarrheal disease. J Glob Health. 2014;4(1):1-11.

42. Kinyoki DK, Manda SO, Moloney GM, Odundo EO, Berkley JA, Noor AM, et al. Modelling the ecological comorbidity of acute respiratory infection, diarrhoea and stunting among children under the age of 5 years in Somalia. Int Stat Rev. 2017;85(1):164-76. https://doi.org/10.1111/insr.12206 PMid:28450758

43. Musa HA, Holi MA, Hussein ME, Shikeiri AB. Faecal contamination of feeding bottles contents, among artificially fed children. Sudan J Med Sci. 2009;4(2):1-4. https://doi. org/10.4314/sjms.v4i2.44901

44. Kim HY, Han Y, Pyun Y, Kim J, Ahn K, Lee SI. Asia pacific allergy respiratory symptoms in infants. Asia Pac Allergy. 2011;1(1):30-5. https://doi.org/10.5415/apallergy.2011.1.1.30

45. Brhanu H, Negese D, Gebrehiwot M. Determinants of acute diarrheal disease among under-five children in Pawi hospital, Northwest Ethiopia, 2013/14. Am J Pediatr. 2013;314(6):68-75. https://doi.org/10.11648/j.ajp.20170306.12

46. Hsu NY, Wu PC, Bornehag CG, Sundell J, Su HJ. Feeding bottles usage and the prevalence of childhood allergy and asthma. Clin Dev Immunol. 2012;2012:158248. https://doi. org/10.1155/2012/158248

PMid:22291844

47. Melo AM, Kassar SB, Lira PI, Coutinho SB, Eickmann SH, Lima MC. Characteristics and factors associated with health care in children younger than 1 year with very low birth weight. J Pediatr. 2013;89(1):75-82. https://doi.org/10.1016/j.jpedp.2012.07.001

48. Sonneveldt E, Plosky WD, Stover J. Linking high parity and maternal and child mortality: What is the impact of lower health services coverage among higher order births? BMC Public Health. 2013;13 Suppl 3:S7. https://doi. org/10.1186/1471-2458-13-s3-s7 PMid:24564721

49. Grundy E, Kravdal $\varnothing$. Do short birth intervals have longterm implications for parental health? Results from analyses 
of complete cohort Norwegian register data. J Epidemiol Community Health. 2014;68(10):958-64. https://doi.org/10.1136/ jech-2014-204191

PMid:25009153

50. Khan JR, Awan N. A comprehensive analysis on child mortality and its determinants in Bangladesh using frailty models. Arch Public Health. 2017;75(1):1-10. https://doi.org/10.1186/ s13690-017-0224-6

51. Costello CA. Maternal and Child Health in Rural Uganda: The Role of Nutrition, Mortality and Depletion; 1986. Available from: https://www.repository.upenn.edu/dissertations/aai8703193. [Last accessed on 2019 Dec 10].

52. Adam I, Ismail MH, Nasr AM, Prins MH, Smits LJ. Low birth weight, preterm birth and short interpregnancy interval in Sudan. J Matern Fetal Neonatal Med. 2009;22(11):1068-71. https://doi. org/10.3109/14767050903009222

PMid:19900046

53. Andriano L, Monden CW. Maternal education on child mortality: Evidence from a quasi-experiment in Malawi and Uganda. In: The 2017 International Population Conference, Cape Town, South Africa; 2017. p. 1-7. https://doi.org/10.1007/ s13524-019-00812-3

54. Natarajan V. Does maternal education really improve child health? IOSR J Dent Med Sci. 2013;4(4):7-9.

55. Hassan AA, Abubaker MS, Radi EA, Adam I. Education, prenatal care, and poor perinatal outcome in Khartoum, Sudan. Int $J$ Gynaecol Obstet. 2009;105(1):66-7. https://doi.org/10.1016/j. ijgo.2008.10.026 PMid:19062014

56. Ali AA, Mohammed AA, Sulaiman MA. Education, poor antenatal care coverage and teenage pregnancy at Kassala Hospital, Eastern Sudan. J Public Health Epidemiol. 2011;3(13):642-4. https://doi.org/10.5897/jphe11.161

57. Cochrane SH, Leslie J, O'Hara DJ. Parental education and child health: Intracountry evidence. Health Policy Educ. 1982;2(3-4):213-50. https://doi. org/10.1016/0165-2281(82)90011-x

PMid:10298649

58. Rammohan A, Awofeso N, Fernandez RC. Paternal education status significantly influences infants' measles vaccination uptake, independent of maternal education status. BMC Public Health. 2012;12(336):1-7. https://doi. org/10.1186/1471-2458-12-336

59. Ayoub AS. Effects of women's schooling on contraceptive use and fertility in Tanzania. Afr Popul Stud. 2004;19(2):139-57.

60. das Gupta M, Engelman R, Levy J, Luchsinger G, Merrick T, Rosen JE. State of World Population 2014. New York: UNFPA; 2014. p. 1-136.

61. Farhadian A, Chan VS, Farhadian H, Farhadian H. Addressing household food insecurity using the household food insecurity access scale (HFIAS) in a poor rural community in Sabah, Malaysia. Int J Humanit Soc Sci Invent. 2015;4(8):89-100. https://doi.org/10.1037/e576842013-001

62. Corman H, Noonan K, Carroll A, Reichman NE, Carroll A, Reichman NE. Low-income fathers' access to health insurance. J Health Care Poor Underserved. 2009;20(1):152-64. https:// doi.org/10.1353/hpu. 0.0120 PMid:19202254

63. Okwaraji YB, Cousens S, Berhane Y, Mulholland K, Edmond K Effect of geographical access to health facilities on child mortality in rural Ethiopia: A community based cross sectional study. PLoS One. 2012;7(3):e33564. https://doi.org/10.1371/ journal.pone.0033564 PMid:22428070

64. Abhulimhen-lyoha $\mathrm{BI}$, Omoigberale AI. Malaria comorbidities in patients seen at the children emergency room, University of Benin teaching hospital, Benin city, Nigeria. Ann Biomed Sci. 2012;11(1):16-23. https://doi.org/10.4314/njp.v39i2.7

65. Walker CL, Perin J, Katz J, Tielsch JM, Black RE, Walker CL. Diarrhea as a risk factor for acute lower respiratory tract infections among young children in low income settings. J Glob Health. 2013;3(1):010402. https://doi.org/10.7189/jogh.03.010402 PMid:23826506

66. Etiaba E, Onwujekwe O, Uzochukwu B, Uguru N, Okoronkwo I, Adjagba A. What co-morbidities do people with malaria have and what are their patterns of health seeking in Nigeria? Niger J Clin Pract. 2015;18(1):22-6. https://doi. org/10.4103/1119-3077.154196

PMid:25511339 